\title{
Response of primary producers to the hydrographic variability in the southern region of the California Current System
}

\section{Respuesta de los productores primarios a la variabilidad hidrográfica en la región sur de la corriente de California}

\author{
Jushiro Cepeda-Morales ${ }^{1}$, Reginaldo Durazo², Eduardo Millán-Núñez ${ }^{3}$, Martín De la Cruz-Orozco², \\ Ramón Sosa-Ávalos ${ }^{4}$, T Leticia Espinosa-Carreón ${ }^{5}$, Luis Soto-Mardones ${ }^{6}$, Gilberto Gaxiola-Castro ${ }^{3 \dagger}$ \\ ${ }^{1}$ Laboratorio de Percepción Remota Satelital de Ecosistemas costeros y Oceánicos, CENIT ${ }^{2}$, Universidad \\ Autónoma de Nayarit, Ciudad de la Cultura “Amado Nervo", Tepic, CP 63155, Nayarit, México. \\ 2 Facultad de Ciencias Marinas, Universidad Autónoma de Baja California, Carretera Ensenada-Tijuana, no. \\ 3917, Zona Playitas, CP 22860, Ensenada, Baja California, México. \\ ${ }^{3}$ Centro de Investigación Científica y de Educación Superior de Ensenada. Carretera Ensenada-Tijuana, no. \\ 3918, Zona Playitas, CP 22860, Ensenada, Baja California, México. \\ ${ }^{4}$ Centro Universitario de Investigaciones Oceanológicas, Universidad de Colima, Carretera Manzanillo-Barra \\ de Navidad, km 20, CP 28860, Manzanillo, México. \\ ${ }^{5}$ Centro Interdisciplinario de Investigación para el Desarrollo Integral Regional, Instituto Politécnico Nacional, \\ Unidad Sinaloa, Blvd. Juan de Dios Bátiz Paredes, no. 250, San Joachín, CP 81101, Guasave, Sinaloa, México. \\ ${ }^{6}$ Facultad de Ciencias, Universidad del Bío-Bío, Av. Collao 1202, Casilla 5-C. CP 4081112, Concepción, Chile. \\ * Corresponding author. E-mail: jushiro.cepeda@uan.edu.mx
}

\begin{abstract}
The response of primary producers to seasonal and interannual variabilities in the hydrographic conditions observed between 1997 and 2012 is analyzed for the southern portion of the California Current System (CCS). The analysis uses the optimum rate of primary productivity $(\mathrm{PP})$ normalized by units of chlorophyll $(\mathrm{Chla})$ in the water column $\left(P_{\text {opt }}^{B}\right)$ and Chla concentration. In situ PP estimations using the ${ }^{14} \mathrm{C}$ method were obtained as part of the seasonal cruises conducted by the Investigaciones Mexicanas de la Corriente de California program. Supplementary data included sea surface temperature (SST) as measured by the AVHRR sensor from 1985-2009. We found the mean value of $P_{o p t}^{B}$ to be at $5.1 \pm 3.3 \mathrm{mg} \mathrm{C} \cdot(\mathrm{mg} \mathrm{Chla})^{-1} \cdot \mathrm{h}^{-1}$, with maximum ranges of 0.5 and $17.5 \mathrm{mg} \mathrm{C} \cdot(\mathrm{mg} \mathrm{Chla})^{-1} \cdot \mathrm{h}^{-1}$. The relationship between $P_{o p t}^{B}$ and SST suggested a phytoplankton community change at around $19^{\circ} \mathrm{C}$, which characterized the transitional nature of the southern portion of the CCS. SST data suggested, on the one hand, that on average the $19^{\circ} \mathrm{C}$ isotherm is located in the vicinity of Punta Eugenia and, on the other, that its spatial variability defined the alternating cool-warm conditions. At the seasonal scale, this isotherm showed a marked latitudinal displacement (from $24^{\circ} \mathrm{N}$ to $32^{\circ} \mathrm{N}$ ), which was observed to be even out of this range during interannual events associated with El Niño/La Niña. Under both cool-warm hydrographic conditions, the phytoplanktonic community showed large $P_{\text {opt }}^{B} \operatorname{rates}\left(\sim 6 \mathrm{mg} \mathrm{C} \cdot\left(\mathrm{mg} \mathrm{Chla}^{-1} \cdot \mathrm{h}^{-1}\right)\right.$. At the interannual scale, $P_{\text {opt }}^{B}$ changes were associated to changes in the abundance and composition of nano-microphytoplankton. Additionally, data suggested that high PP rates during warm periods could be attributed to an enhanced picoplankton contribution.
\end{abstract}

Key words: primary production, chlorophyll, phytoplankton community, seasonal variability, California Current.

RESUMEN. Se analizó la respuesta de los productores primarios a la variabilidad estacional e interanual de las condiciones hidrográficas en la región sur del Sistema de la Corriente de California (SCC) entre 1997 y 2012. El análisis se basa en la tasa óptima de productividad primaria $(\mathrm{PP})$ normalizada por unidad de clorofila $(\mathrm{Chl} a)$ en la columna de agua $\left(P_{o p t}^{B}\right)$ y en la concentración de Chla. Como parte del monitoreo que realiza el programa de Investigaciones Mexicanas de la Corriente de California, se obtuvieron para cada estación del año datos de PP in situ con la técnica de ${ }^{14} \mathrm{C}$. La información se complementó con datos de la temperatura superficial del mar (TSM) medida por el sensor AVHRR de 1985 a 2009. El análisis de los datos de TSM demostró que, en el promedio de largo periodo, la isoterma de $19^{\circ} \mathrm{C}$ se ubicó en las inmediaciones de punta Eugenia y que su variabilidad espacial permite seguir la alternancia del cambio entre las condiciones frías y cálidas. En la escala estacional, esta isoterma presentó un marcado desplazamiento latitudinal (de $24^{\circ} \mathrm{N}$ a $32^{\circ} \mathrm{N}$ ), y se extiendió aún más durante eventos interanuales asociados a El Niño/La Niña. El valor promedio del $P_{o p t}^{B}$ fue de $5.1 \pm 3.3 \mathrm{mg} \mathrm{C} \cdot(\mathrm{mg} \mathrm{Chla})^{-1} \cdot \mathrm{h}^{-1}$ y varió de 0.5 a $17.5 \mathrm{mg} \mathrm{C}$. $(\mathrm{mg} \mathrm{Chl} a)^{-1} \cdot \mathrm{h}^{-1}$. La relación entre el $P_{\text {opt }}^{B}$ y la TSM sugiere un cambio en la comunidad del fitoplancton a los $19{ }^{\circ} \mathrm{C}$, lo que se consideró como una respuesta al carácter transicional del SCC. La comunidad fitoplanctónica mantuvo altas tasas promedio de $P_{o p t}^{B}\left(\sim 6 \mathrm{mg} \mathrm{C} \cdot\left(\mathrm{mg} \mathrm{Chla}^{-1} \cdot \mathrm{h}^{-1}\right)\right.$ en ambas condiciones hidrográficas (frío/cálido). Las variaciones en la escala estacional e interanual del $P_{\text {opt }}^{B}$ estuvieron asociados a cambios en la composición y abundancia del nano-microfitoplancton. Los datos sugieren que las altas tasas PP en periodos cálidos pueden atribuirse a la contribución del picoplancton.

Palabras clave: productividad primaria, clorofila, comunidad del fitoplancton, variaciones estacionales, corriente de California. 


\section{INTRODUCTION}

The California Current System (CCS) is one of the most productive ecosystems in the world (Carr 2006). The southern portion of the CCS off the coast of Baja California (Mexico) is a transition zone with a clear seasonal signal. During winter and spring it is mainly influenced by subarctic waters, and during summer and autumn it is influenced by waters from the tropical Pacific off the coast of Mexico (Durazo and Baumgartner 2002, Durazo 2015). Off Baja California, the CCS is characterized by upwelling favorable conditions (Linacre et al. 2010), the formation of mesoscale eddies (Espinosa-Carreón et al. 2012), and the influence of interannual (El Niño and La Niña) and decadal events. Altogether, these factors control primary productivity (PP) and thus productivity in the pelagic ecosystem (EspinosaCarreón et al. 2004).

Since 1997, the Investigaciones Mexicanas de la Corriente de California program (Mexican Research Program of the California Current; IMECOCAL, for its acronym in Spanish) has conducted in situ measurements of phytoplankton PP. These measurements have allowed us to identify temporal variations in PP at seasonal and interannual scales (Gaxiola-Castro et al. 2010), as well as significant differences in variations of integrated PP between summer and autumn (Aguirre-Hernández et al. 2004). Moreover, evidence indicates that the decrease in biomass and PP in the region is a consequence of interannual variations, such as the one associated with the anomalous intrusion of subarctic water (Espinosa-Carreón et al. 2015).

The response of primary producers to changes in oceanographic conditions, in terms of biomass, which is estimated using the concentration of chlorophyll (Chla), off the coast of Baja California has been documented based on both measurement data (Gaxiola-Castro et al. 2008, 2010) and remote sensing data (Espinosa-Carreón et al. 2004). On a seasonal scale, the southern portion of the CCS typically shows high Chla concentrations during spring due to the intensification of coastal upwelling, but these concentrations decrease during summer due to the combined effect of the weakening of upwelling favorable winds and the increase in water stratification. At the interannual scale, Chla concentrations show negative anomalies during warm periods associated with the sinking of the pycnocline, and during cold periods, when the pycnocline rises, phytoplankton biomass generally shows positive anomalies (Gaxiola-Castro et al. 2010).

One way to measure oceanic productivity is by using the optimal rate of carbon fixation normalized per unit of Chla $\left(P_{o p t}^{B}\right) . P_{o p t}^{B}$ is a photosynthetic parameter that responds to light and nutrient conditions in the euphotic zone (Behrenfeld and Falkowsky 1997), and it can therefore provide information on the characteristics of the phytoplankton community under different environmental conditions. The strength of this parameter lies on the fact that each phytoplankton group

\section{INTRODUCCIÓN}

El Sistema de la Corriente de California (SCC) es uno de los ecosistemas más productivos a nivel global (Carr 2006). La porción sur del SCC frente a las costas de Baja California (México) es una zona de transición con una clara señal estacional. En invierno y primavera recibe la influencia principalmente de agua de origen subártico, mientras que en verano y otoño recibe contribuciones de agua del Pacífico tropical frente a las costas mexicanas (Durazo y Baumgartner 2002, Durazo 2015). Algunos rasgos característicos del SCC frente a Baja California son las condiciones favorables a las surgencias costeras (Linacre et al. 2010), la generación de remolinos de mesoescala (Espinosa-Carreón et al. 2012) y la influencia de eventos interanuales (El Niño y La Niña) y decadales. En conjunto, estos factores controlan la productividad primaria (PP) y, por lo tanto, la productividad del ecosistema pelágico (Espinosa-Carreón et al. 2004).

Desde 1997, el programa de Investigaciones Mexicanas de la Corriente de California (IMECOCAL) ha llevado a cabo mediciones in situ de la PP del fitoplancton. Con estas mediciones se han logrado identificar las variaciones temporales de la PP a escalas estacionales e interanuales (GaxiolaCastro et al. 2010), así como diferencias importantes en las variaciones de la PP integrada entre verano y otoño (AguirreHernández et al. 2004). Por otro lado, se ha podido evidenciar la disminución en biomasa y PP de la región como una respuesta a variaciones interanuales, como la intrusión anómala de agua subártica (Espinosa-Carreón et al. 2015).

Frente a Baja California, la respuesta de los productores primarios a los cambios en las condiciones oceanográficas en términos de su biomasa, estimada por medio de la concentración de clorofila (Chla), ha sido documentada tanto con datos de mediciones (Gaxiola-Castro et al. 2008, 2010) como con datos de sensores remotos (Espinosa-Carreón et al. 2004). A escala estacional, la región sur del SCC típicamente presenta altos valores en la concentración de Chla durante la primavera debido a la intensificación de las surgencias costeras; durante el verano, las concentraciones de Chla disminuyen por el efecto conjunto del debilitamiento de los vientos favorables a las surgencias y el incremento en la estratificación. A escala interanual, las concentraciones de Chla presentan anomalías negativas en periodos cálidos asociados con el hundimiento de la picnoclina; durante los periodos fríos, que son acompañados del levantamiento de la picnoclina, se observan generalmente anomalías positivas en la biomasa del fitoplancton (Gaxiola-Castro et al. 2010).

Una forma de medir la productividad oceánica es mediante la tasa óptima de fijación de carbono normalizada por unidad de Chla $\left(P_{o p t}^{B}\right)$. La $P_{o p t}^{B}$ es un parámetro fotosintético que responde a las condiciones de luz y nutrientes en la zona eufótica (Behrenfeld y Falkowsky 1997) y, por tanto, puede proporcionar información de las características de la comunidad del fitoplancton en respuesta a las condiciones ambientales. $\mathrm{Su}$ fortaleza recae en que cada grupo del 
reaches a $P_{o p t}^{B}$ value at a specific temperature due to its enzymatic response (Eppley 1972). At a global level, the ratio between the $P_{o p t}^{B}$ parameter and sea surface temperature (SST) is closely related to large ecosystems (Behrenfeld and Falkowsky 1997). However, at a regional level, its application as an indicator of the response of the phytoplankton community to changes in environmental conditions has not been thoroughly explored. In order to understand the response of a pelagic ecosystem to changes in oceanographic conditions, the relation between the $P_{o p t}^{B}$ parameter and SST was analyzed. Our objective is to study the response of primary producers to the hydrographic variations in the transition zone located off the coast of the Baja California peninsula at seasonal and interannual scales.

\section{MATERIALS AND METHODS}

Data analyzed in the present study were collected during 47 oceanographic campaigns. These campaigns were carried out between 1997 and 2012 in the southern region of the CCS, off the Baja California Peninsula. In each oceanographic campaign, in situ experiments were carried out in order to determine PP in the euphotic zone (Fig. 1). The ${ }^{14} \mathrm{C}$ fixation rate was measured with the light-dark bottle method through experiments that were carried out at around noon (local time). Water samples were taken at optical depths corresponding to $100 \%, 50 \%, 30 \%, 20 \%, 10 \%$, and $1 \%$ of surface irradiance. Physical depths were calculated by using the Beer law: $Z=\ln \left(\mathrm{E}_{\mathrm{o}} / \mathrm{E}_{\mathrm{z}}\right) / K_{\mathrm{d}}$, where $Z$ is depth, $\mathrm{E}_{\mathrm{o}}$ is surfce irradiance, $\mathrm{E}_{\mathrm{z}}$ is irradiance at depth $Z$, and $K_{\mathrm{d}}$ is the mean diffuse attenuation coefficient, which was estimated by using depth measurements from the Secchi disc $\left(Z_{\mathrm{d}}\right)$ and applying the ratio for oceanic waters $K_{\mathrm{d}}=1.7 / Z_{\mathrm{d}}$. Water samples were collected with 5-L Niskin bottles mounted on a General Oceanics rosette. To minimize sample contamination, silicone gaskets and elastics were used for the bottles. Conductivity, temperature, and pressure were measured with a factory calibrated CTD SeaBird 911plus at each station.

Water samples collected at each depth were filtered with a $150-\mu \mathrm{m}$ mesh to remove macrozooplankton and placed in 250-mL polycarbonate bottles, which were inoculated with $5 \mu \mathrm{Ci}$ of $\mathrm{NaH}^{14} \mathrm{CO}_{3}$. For each optical depth, 1 dark and 2 light bottles were used. They were placed in transparent acrylic tubes. Bottle arrangements were then returned to the sampling depth, and they were incubated for 1.5 to $2.0 \mathrm{~h}$. After incubation, samples were filtered through a 45- $\mu \mathrm{m}$ GN-6 membrane. Each filter was placed in $20-\mathrm{mL}$ glass vials, and $0.5 \mathrm{~mL}$ of $10 \% \mathrm{HCl}$ were added to remove $\mathrm{NaH}^{14} \mathrm{CO}_{3}$ excess. After $3 \mathrm{~h}, 10 \mathrm{~mL}$ of scintillation cocktail (Ecolite) were added to each vial. Radioactivity was determined with a Beckman LS-6500 scintillation counter. PP estimations were calculated using disintegrations per minute and corrected by the dark bottle (Parsons et al. 1984). PP profiles were normalized using the Chla concentration, and $P_{o p t}^{B}$ in the water fitoplancton alcanza un valor de $P_{o p t}^{B}$ a una temperatura específica debido a su respuesta a nivel enzimático (Eppley 1972). A nivel global, la relación del parámetro $P_{o p t}^{B}$ con la temperatura superficial del mar (TSM) está íntimamente relacionada con los grandes ecosistemas (Behrenfeld y Falkowsky 1997). Sin embargo, su aplicación a nivel regional como un indicador de la respuesta comunitaria del fitoplancton a los cambios en las condiciones ambientales ha sido poco explorada. Para comprender la respuesta del ecosistema pelágico a cambios en las condiciones oceanográficas, se analizó la relación del parámetro $P_{o p t}^{B}$ con la TSM. Nuestro objetivo es estudiar la respuesta de los productores primarios a las variaciones hidrográficas a escalas estacionales e interanuales en la región de transición frente a la península de Baja California.

\section{MATERIALES Y MÉTODOS}

Los datos para el presente trabajo provinieron de 47 campañas oceanográficas realizadas en la región sur del SCC, frente a la península de Baja California, entre 1997 y 2012. En cada campaña oceanográfica se desarrollaron experimentos in situ para determinar la PP de la zona eufótica (Fig. 1). La tasa de fijación de ${ }^{14} \mathrm{C}$ se midió con el método de la botella clara-oscura mediante experimentos desarrollados alrededor del mediodía local. Se tomaron muestras de agua a las profundidades ópticas correspondientes al 100\%, 50\%, 30\%, $20 \%, 10 \%$ y $1 \%$ de la irradiancia superficial. Las profundidades físicas fueron calculadas utilizando la ley de Beer: $Z=$ $\ln \left(\mathrm{E}_{\mathrm{o}} / \mathrm{E}_{\mathrm{z}}\right) / K_{d}$, donde $Z$ es la profundidad; $\mathrm{E}_{\mathrm{o}}$ es la irradiancia superficial; $\mathrm{E}_{\mathrm{z}}$ es la irradiancia a la profundidad $Z$; y $K_{\mathrm{d}}$ es el promedio del coeficiente de atenuación de la luz difusa, que fue estimado con la lectura del disco Secchi $\left(Z_{\mathrm{d}}\right)$ aplicando la relación para aguas oceánicas de $K_{\mathrm{d}}=1.7 / Z_{\mathrm{d}}$. Las muestras de agua fueron obtenidas con botellas Niskin de $5 \mathrm{~L}$ montadas en una roseta General Oceanics. Para minimizar la contaminación de las muestras, las ligas y los empaques de las botellas utilizadas fueron de silicón. En cada estación se realizó una hidrocala para medir la conductividad, temperatura y presión usando un CTD SeaBird 911plus con calibración de fábrica.

El agua recolectada a cada profundidad se filtró con una malla de $150 \mu \mathrm{m}$ para remover el macrozooplancton y se colocó en botellas de policarbonato de $250 \mathrm{~mL}$, las cuales fueron inoculadas con $5 \mu \mathrm{Ci}$ de $\mathrm{NaH}^{14} \mathrm{CO}_{3}$. Para cada profundidad óptica, se utilizaron 2 botellas claras y 1 oscura, las cuales se colocaron en tubos de acrílico transparente. Posteriormente, los arreglos fueron regresados a la profundidad de muestreo y se incubaron durante 1.5 a $2.0 \mathrm{~h}$. Finalizada la incubación, las muestras se filtraron a través de una membrana GN-6 de $45 \mu \mathrm{m}$ de poro. Cada filtro se colocó en viales de vidrio de $20 \mathrm{~mL}$, a los que se les adicionaron $0.5 \mathrm{~mL}$ de $\mathrm{HCl}$ al $10 \%$ para eliminar el exceso de $\mathrm{NaH}^{14} \mathrm{CO}_{3}$. Después de $3 \mathrm{~h}$, a cada vial se le colocaron $10 \mathrm{~mL}$ de solución de centelleo (Ecolite). La radioactividad fue determinada con un 


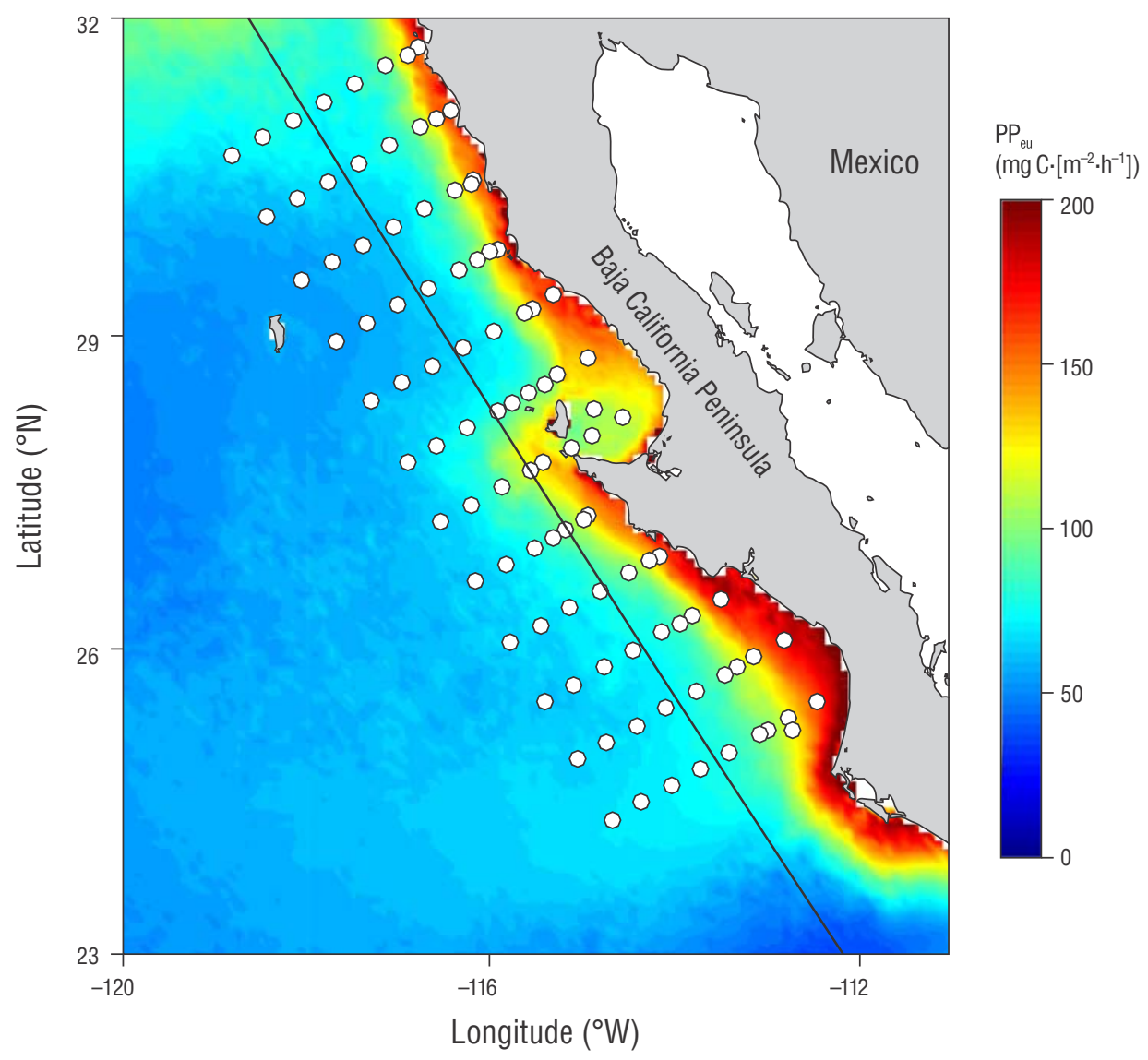

Figure 1. IMECOCAL monitoring network (white circles). Circles indicate the stations where in situ experiments were carried out on at least one occasion to determine primary productivity (PP). The color scale shows integrated PP in the euphotic zone $\left(\mathrm{PP}_{\mathrm{eu}}\right)$ as calculated with the Vertically Generalized Production Model (Behrenfeld and Falkowski 1997); map shows the mean value calculated using the monthly data measured by MODIS-Aqua from 2002 to 2016 (https: //oceancolor.gsfc.nasa.gov/). The transect located parallel to the coast (black line) was used to generate Figure 5.

Figura 1. Red de monitoreo del programa IMECOCAL (círculos blancos). Los círculos indican las estaciones donde se realizaron experimentos in situ en al menos una ocasión para determinar la productividad primaria (PP). La escala de colores muestra la PP integrada en la zona eufótica $\left(\mathrm{PP}_{\mathrm{eu}}\right)$ calculada con el Vertically Generalized Production Model (Behrenfeld y Falkowski 1997); se presenta el valor promedio calculado con los datos mensuales medidos desde 2002 hasta 2016 por el MODIS-Aqua (https://oceancolor.gsfc.nasa.gov/). El transecto paralelo a la costa (línea negra) fue utilizado para generar la Figura 5.

column $\left(\mathrm{mg} \mathrm{C} \cdot(\mathrm{mg} \mathrm{Chla})^{-1} \cdot \mathrm{h}^{-1}\right)$ was defined as the maximum observed value in each PP profile normalized by Chla. All homogeneous profiles were discarded from the database. In total, 430 in situ PP experiments were carried out, covering almost $100 \%$ of the stations from the IMECOCAL monitoring network (Fig. 1). Variations in PP as a response to hydrographic conditions were analyzed based on the empirical regional relation between $P_{o p t}^{B}$ and SST (equation 1) described by Cepeda-Morales et al. (2010). This regional empirical adjustment estimates $P_{o p t}^{B}$ as a function of satellitederived temperature $(T)$ and allows the estimation of PP integrated to the euphotic zone (Behrenfeld and Falkowski 1997) (Fig. 1). contador de centelleo Beckman LS-6500. La PP se calculó utilizando los decaimientos por minuto y fue corregida por la botella oscura (Parsons et al. 1984). Los perfiles de PP se normalizaron con la concentración de Chla, y se determinó la $P_{o p t}^{B}$ en la columna de agua $\left(\mathrm{mg} \mathrm{C} \cdot(\mathrm{mg} \mathrm{Chla})^{-1} \cdot \mathrm{h}^{-1}\right)$ como el máximo observado en cada perfil de PP normalizado por Chla. Se descartaron todos los perfiles homogéneos de la base de datos. En total se realizaron 430 experimentos de PP in situ, con una cobertura espacial cercana al $100 \%$ de las estaciones de la red de monitoreo IMECOCAL (Fig. 1). Las variaciones de la PP como respuesta a las condiciones hidrográficas fueron analizadas partiendo de la relación empírica regional entre el $P_{o p t}^{B}$ y la TSM (ecuación 1) propuesta por

$$
P_{\text {opt }}^{B}=4.15 \times 10^{-4} T^{7}-0.0532 T^{6}+2.899 T^{5}-87.24 T^{4}+1567.1 T^{3}-16745 T^{2}+98946 T-2.491 \times 10^{5}
$$


To quantify the Chla concentration $\left(\mathrm{mg} \mathrm{m}^{-3}\right)$ at each optical depth, $1 \mathrm{~L}$ of water was collected and filtered through $\mathrm{GF} / \mathrm{F}$ Whatman glass fiber filters at a positive pressure. Filters were then placed in HistoPrep tissue capsules, properly labeled, and stored in liquid nitrogen for later analysis in the laboratory. At the laboratory, the Chla sample was placed in $10 \mathrm{~mL}$ of $90 \%$ acetone for $24 \mathrm{~h}$ at $\sim 4^{\circ} \mathrm{C}$ in complete darkness (Venrick and Hayward 1984). Pigment concentration was quantified using the fluorometric method (Yentsch and Menzel 1963, Holm-Hansen 1965) and calibrating the fluorometer with a pattern of Chla (Sigma).

To determine phytoplankton composition, water samples were collected during the oceanographic cruises in the 2001-2008 period. Samples were collected at a depth of $10 \mathrm{~m}$ and stored in $250-\mathrm{mL}$ dark bottles with formaldehyde at a $\mathrm{pH}$ of 7.5 to 8.0. Phytoplankton analysis was carried out within the first 2 months after each cruise. To perform cell counts, $50 \mathrm{~mL}$ of seawater were concentrated in a sedimentation chamber. Phytoplankton counting and identification were done using an inverted microscope with $16 \times$ and $40 \times$ lenses (ZEISS VERT. A1).

SST data, measured with the AVHRR-Pathfinder sensor and processed with version 5 of the algorithm, were obtained from https://podaac.jpl.nasa.gov/. The SST data for the 1985-2009 period correspond to global images of level 3 monthly composites, which correspond to monthly average measurements adjusted to a regular georeferenced grid with a spatial resolution of $4 \mathrm{~km}$.

\section{RESULTS}

The $P_{\text {opt }}^{B}$ parameter (Fig. 2a) is a product of phytoplankton response to light and nutrient availability, the composition of the dominant community, and temperature. $P_{o p t}^{B}$ ranged from 0.5 to $17.5 \mathrm{mg} \mathrm{C} \cdot(\mathrm{mg} \mathrm{Chla})^{-1} \cdot \mathrm{h}^{-1}$, with an overall average of $5.1 \pm 3.3 \mathrm{mg} \mathrm{C} \cdot(\mathrm{mg} \mathrm{Chla})^{-1} \cdot \mathrm{h}^{-1}$. Most high values were located between $50 \%$ and $30 \%$ of irradiance, that is to say, within the first $25 \mathrm{~m}$ of the water column (Fig. 2b).

Average $P_{o p t}^{B}$ estimates per cruise showed wide scattering of values (Fig. 3a). The temporal variation shows that dispersion of measurements was smaller for the expeditions carried out from 1998 to 2002. In addition to the larger dispersion of the measured values, an increase in monthly $P_{o p t}^{B}$ was observed after 2003. These results provide initial evidence on the complexity of the response of primary producers to variations in regional hydrographic conditions. The empirical adjustment between $P_{o p t}^{B}$ and SST showed a curve with 2 maxima (Fig. 3b), both with a value of $\sim 6.0 \mathrm{mg} \mathrm{C} \cdot(\mathrm{mg} \mathrm{Chla})^{-1} \cdot \mathrm{h}^{-1}$. The first maximum was located at $17{ }^{\circ} \mathrm{C}$ and the second at $21.5^{\circ} \mathrm{C}$, and both were separated by a relative minimum value at $19{ }^{\circ} \mathrm{C}$. This decrease in the $P_{\text {opt }}^{B}$ curve at $19^{\circ} \mathrm{C}$ suggests that the phytoplankton community showed a physiological response to changes between warm and cold hydrographic conditions.
Cepeda-Morales et al. (2010). El ajuste empírico regional calcula el $P_{o p t}^{B}$ como función de la temperatura satelital $(T)$ y permite estimar la PP integrada de la zona eufótica (Behrenfeld y Falkowski 1997) (Fig. 1).

Para cuantificar la concentración de Chla $\left(\mathrm{mg} \cdot \mathrm{m}^{-3}\right)$, a cada profundidad óptica se recolectó $1 \mathrm{~L}$ de agua, que se filtró a través de filtros de fibra de vidrio GF/F Whatman a presión positiva. Enseguida, los filtros fueron colocados en cápsulas para tejido HistoPrep, debidamente etiquetados y almacenados en nitrógeno líquido para su análisis posterior en el laboratorio. En el laboratorio, la muestra con Chla se colocó en $10 \mathrm{~mL}$ de acetona al $90 \%$ durante $24 \mathrm{~h}$ a $\sim{ }^{\circ} \mathrm{C}$ en completa oscuridad (Venrick y Hayward 1984). Se cuantificó la concentración del pigmento con el método fluorométrico (Yentsch y Menzel 1963, Holm-Hansen 1965) calibrado con un patrón de Chla (Sigma).

Para determinar la composición del fitoplancton, se tomaron muestras de agua en los cruceros realizados en los eneros del periodo 2001-2008. Las muestras se recolectaron a $10 \mathrm{~m}$ de profundidad y se almacenaron en botellas oscuras de $250 \mathrm{~mL}$ preservadas con formaldehído a un $\mathrm{pH}$ de entre 7.5 y 8.0. El análisis del fitoplancton se llevó a cabo entre los 2 primeros meses después de cada crucero. Para los conteos de células, se concentraron $50 \mathrm{~mL}$ de agua de mar en una cámara de sedimentación. El conteo y la identificación del fitoplancton se realizaron con un microscopio invertido con objetivos de 16× y 40× (ZEISS VERT. A1).

Los datos de TSM, medidos con el sensor AVHRRPathfinder y procesados con el algoritmo versión 5, se obtuvieron del sitio https://podaac.jpl.nasa.gov/. Los datos de TSM para el periodo de 1985 a 2009 corresponden a imágenes globales de compuestos mensuales L3, las cuales corresponden a promedios de las mediciones tomadas en un mes y ajustadas a una malla regular georeferenciada con una resolución espacial de $4 \mathrm{~km}$.

\section{RESUlTADOS}

El parámetro $P_{o p t}^{B}$ (Fig. 2a) es producto de la respuesta del fitoplancton a la disponibilidad de luz y nutrientes, además de la composición comunitaria dominante y de la temperatura. Los valores de $P_{o p t}^{B}$ variaron entre $0.5 \mathrm{y}$ $17.5 \mathrm{mg} \mathrm{C} \cdot(\mathrm{mg} \mathrm{Chla})^{-1} \cdot \mathrm{h}^{-1}$, con un promedio general de $5.1 \pm$ $3.3 \mathrm{mg} \mathrm{C} \cdot(\mathrm{mg} \mathrm{Chla})^{-1} \cdot \mathrm{h}^{-1}$. La mayoría de los valores altos se localizaron entre el $50 \%$ y el $30 \%$ de la irradiancia, esto es, dentro de los primeros $25 \mathrm{~m}$ de la columna de agua (Fig. 2b).

Las estimaciones de $P_{\text {opt }}^{B}$ promedio por crucero mostraron amplia dispersión de los valores (Fig. 3a). La variación temporal muestra que la dispersión de las mediciones fue menor para las expediciones realizadas entre 1998 y 2002. Posterior a 2003, además de una mayor dispersión de los valores medidos, se observó un aumento en los promedios mensuales de $P_{o p t}^{B}$. Estos resultados proporcionan una primera evidencia de la complejidad de las respuestas de los productores primarios 

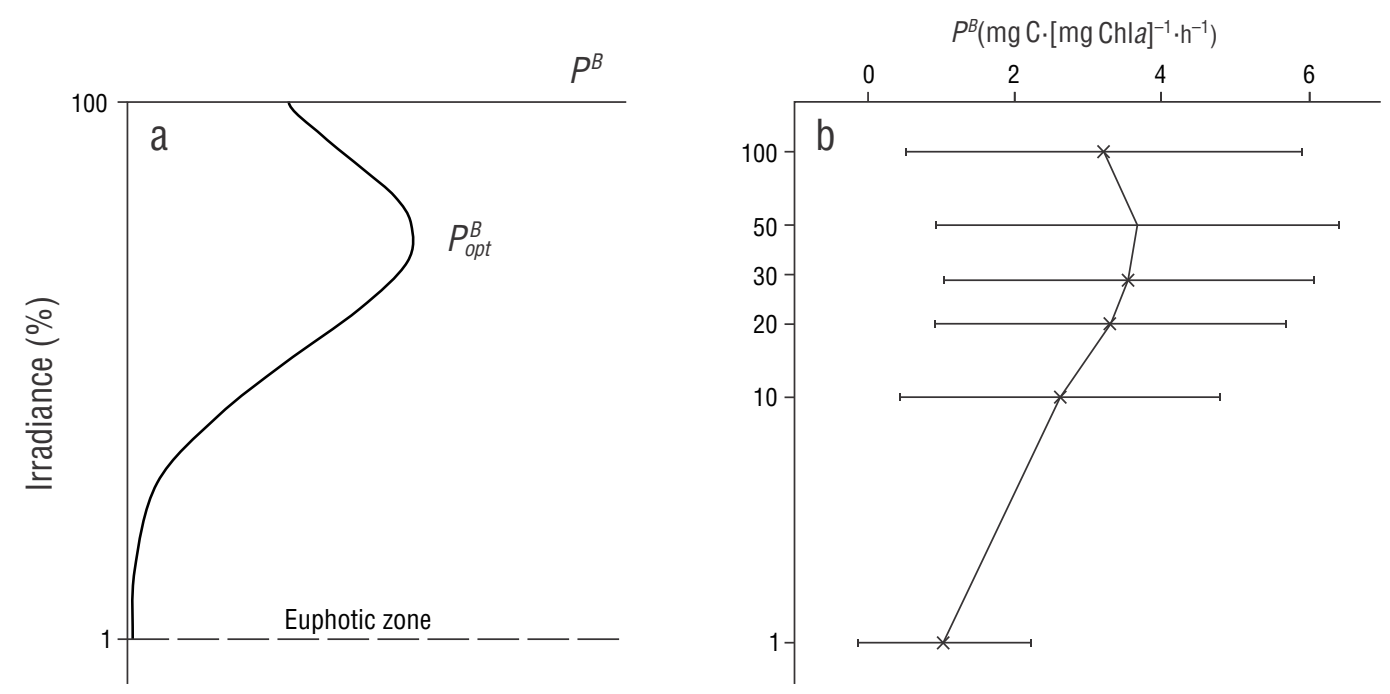

Figure 2. (a) Diagram of a vertical primary productivity profile normalized per unit of chlorophyll $\left(P^{B}\right)$ in relation to light attenuation (percentage); the position of the photosynthetic parameter $P_{o p t}^{B}\left(\mathrm{mg} \mathrm{C} \cdot(\mathrm{mg} \mathrm{Chla})^{-1} \cdot \mathrm{h}^{-1}\right)$ is indicated. (b) Vertical distribution of total $P^{B}$ measurements taken between 1998 and 2012; the diagram shows the average $(\times)$ and standard deviation (bars) for each irradiance level at which in situ incubations were performed.

Figura 2. (a) Esquema de un perfil vertical de productividad primaria normalizada por unidad de clorofila $\left(P^{B}\right)$ con relación a la atenuación de la luz (en porcentaje); se indica la posición del parámetro fotosintético $P_{o p t}^{B}\left(\mathrm{mg} \mathrm{C} \cdot[\mathrm{mg} \mathrm{Chla}]^{-1} \cdot \mathrm{h}^{-1}\right)$. (b) Distribución vertical del total de mediciones de $P^{B}$ realizadas entre 1998 y 2012; se muestran el promedio $(\times$ ) y la desviación estándar (barras) para cada nivel de irradiancia donde se realizaron las incubaciones in situ.

In order to examine the importance of the $19{ }^{\circ} \mathrm{C}$ surface isotherm as an indicator of the cold/warm regime change, the geographic position of this temperature value was determined on each monthly image (Fig. 4). In the region closest to the coast, the spatial dispersion of isotherms shows large latitudinal variability ( $\sim 8^{\circ}$ latitude) during the 25 years, which indicates alternating upwelling events. The average position (thick black contour) of the $19{ }^{\circ} \mathrm{C}$ isotherm is located approximately $27^{\circ} \mathrm{N}$ (off Punta Eugenia), and it is also asymmetrically located with respect to the spatial distribution of the isotherms.

The SST spatiotemporal evolution shows that the geographic amplitude of the $19{ }^{\circ} \mathrm{C}$ isotherm in the study area responds mainly to the seasonal scale, with a latitudinal displacement of up to $\sim 32^{\circ} \mathrm{N}$ during summer and $\sim 24^{\circ} \mathrm{N}$ during winter (Fig. 5). In addition to the seasonal scale, the displacement of the isotherm shows the effect of warm and cold interannual events during some years. The temperature decrease in 1989 , when the $19^{\circ} \mathrm{C}$ isotherm moved further south, and the cold events from 1999-2001 and 2006 are noteworthy. Warm periods were observed during 1992-1993, 1996-1998, 2002-2005, and 2007.

The interannual variability was also observed in Chla concentrations at $20 \mathrm{~m}$ depth. The anomalies of the Chla regional average at $20 \mathrm{~m}$ depth, which is approximately the depth of the average $P_{\text {opt }}^{B}$ value (Fig. 2b), show the marked interannual changes in phytoplankton biomass (Fig 6a). In a las variaciones en las condiciones hidrográficas de la región. El resultado del ajuste empírico entre el parámetro $P_{o p t}^{B}$ y la TSM presentó una curva con 2 máximos (Fig. 3b), ambos de $\sim 6.0 \mathrm{mg} \mathrm{C} \cdot(\mathrm{mg} \mathrm{Chla})^{-1} \cdot \mathrm{h}^{-1}$. El primer máximo ocurrió a los $17.0^{\circ} \mathrm{C}$ y el segundo a $21.5^{\circ} \mathrm{C}$, ambos separados por un mínimo relativo a los $19^{\circ} \mathrm{C}$. Este descenso en la curva de $P_{o p t}^{B}$ en $19^{\circ} \mathrm{C}$ sugiere una respuesta fisiológica de la comunidad del fitoplancton al cambio entre las condiciones hidrográficas frías y cálidas.

Con el objetivo de examinar la importancia de la isoterma superficial de $19^{\circ} \mathrm{C}$ como indicador del cambio de régimen frío/cálido, se determinó la posición geográfica del valor de dicha temperatura en las imágenes mensuales (Fig. 4). En la región más costera, la dispersión espacial de las isotermas muestra una gran variabilidad latitudinal $\left(\sim 8^{\circ}\right)$ durante los 25 años, reflejo de la alternancia de surgencias. La posición promedio (contorno grueso de color negro en Fig. 4) de la isoterma de $19^{\circ} \mathrm{C}$ se localizó alrededor de los $27^{\circ} \mathrm{N}$ (frente a punta Eugenia) y se ubicó asimétricamente con respecto a la distribución espacial de las isotermas.

La evolución espaciotemporal de TSM muestra que la amplitud geográfica de la isoterma de $19^{\circ} \mathrm{C}$ en la región de estudio respondió principalmente a la escala estacional, con un desplazamiento latitudinal de hasta $\sim 32^{\circ} \mathrm{N}$ en verano y $\sim 24^{\circ} \mathrm{N}$ en invierno (Fig. 5). Además, el desplazamiento de la isoterma muestra, para ciertos años, el efecto de eventos interanuales cálidos $\mathrm{y}$ fríos. Destacan el enfriamiento 

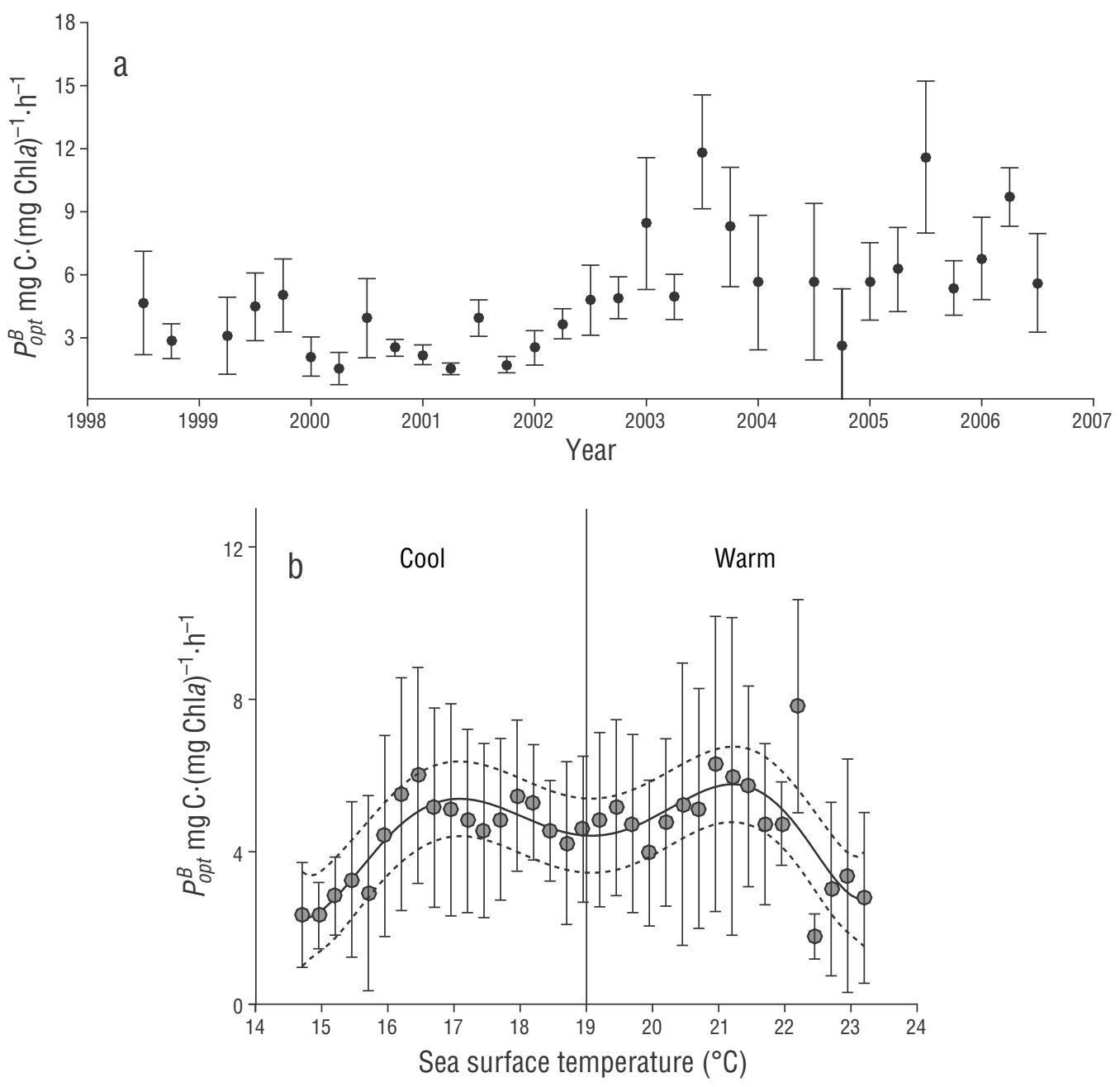

Figure 3. (a) Temporal variation of average optimal rates of carbon fixation $\left(P_{o p t}^{B}, \mathrm{mg} C \cdot[\mathrm{mg} \mathrm{Chla}]^{-1} \cdot \mathrm{h}^{-1}\right)$ per cruise during the period 1998-2007. (b) Empirical relationship between $P_{o p t}^{B}$ and CTD surface sea temperature measurements.

Figura 3. (a) Variación temporal de las mediciones promedio por crucero de la tasa óptima de fijación de carbono ( $P_{o p t}^{B}$, $\mathrm{mg} \mathrm{C} \cdot[\mathrm{mg} \mathrm{Chla}]^{-1} \cdot \mathrm{h}^{-1}$ ) durante el periodo 1998-2007. (b) Relación empírica entre los valores de $P_{o p t}^{B}$ y la temperatura superficial del mar medida con el CTD.

the first 2 years (1998 to 1999), Chla concentration showed negative anomalies. Thereafter, from 2000 to the end of 2002, positive anomalies were observed, with high values during January $2002\left(1.4 \mathrm{mg} \cdot \mathrm{m}^{-3}\right)$. In the pelagic ecosystem, a period of negative anomalies that extended from 2003 to the end of 2007 was recorded. During 2008 and 2010-2011, Chla concentrations were again positive. This alternation of positive and negative Chla anomalies can be contrasted with the interannual changes in the hydrographic and atmospheric conditions of the equatorial region, which are represented by the El Niño Multivariate Enso Index (MEI) for the study period (Fig. 6b). The MEI indicates a salient El Niño event in 1998 (positive anomalies), followed by La Niña favorable conditions (negative anomalies) during 1999-2002. Positive anomalies were observed from late 2002 to mid-2005. ocurrido en 1989, cuando la isoterma de $19{ }^{\circ} \mathrm{C}$ se desplazó más hacia el sur, y los eventos fríos en el periodo 1999-2001 $\mathrm{y}$ en 2006. Los periodos cálidos ocurrieron durante 1992-1993, 1996-1998, 2002-2005 y 2007.

La variabilidad interanual también se reflejó en la concentración de Chla medida a $20 \mathrm{~m}$. Las anomalías del promedio regional de Chla a $20 \mathrm{~m}$, aproximadamente la profundidad del valor promedio de $P_{o p t}^{B}$ (Fig. 2b), demuestran los marcados cambios interanuales en la biomasa del fitoplancton (Fig. 6a). En los primeros 2 años (1998 a 1999), la concentración de Chla presentó anomalías negativas. Posteriormente, desde 2000 hasta finales de 2002, se presentaron principalmente anomalías positivas, con elevados valores durante enero de $2002\left(1.4 \mathrm{mg} \cdot \mathrm{m}^{-3}\right)$. En el ecosistema pelágico, se registró un periodo marcado de anomalías 


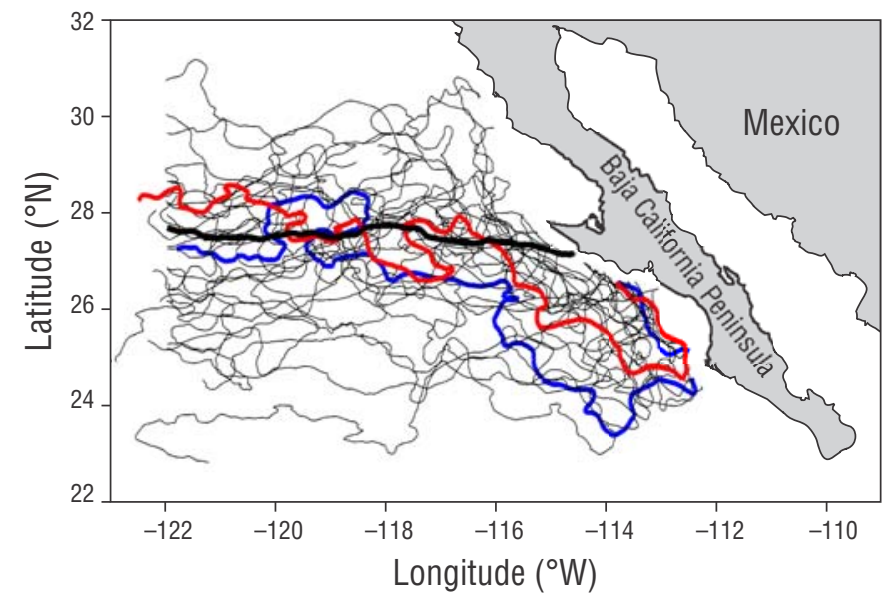

Figure 4. Monthly scatter of the $19^{\circ} \mathrm{C}$ surface isotherm from 1985 to 2009 (thin black lines). The thick black contour indicates the total average. Isotherms for January 1985 and January 2009 are shown in blue and red, respectively. The data correspond to level 3 monthly compounds calculated with AVHRR-PATHFINDER v5.

Figura 4. Dispersión mensual de la isoterma superficial de $19{ }^{\circ} \mathrm{C}$ de 1985 a 2009 (línea fina en negro). El promedio total se representa por el contorno grueso en color negro. Las isotermas de enero 1985 y enero 2009 se muestran en azul y rojo, respectivamente. Los datos corresponden a los compuestos mensuales de nivel 3 nocturnos calculados con el algoritmo del sensor AVHRR-Pathfinder v5.

Significant cold conditions were recorded in 2007-2008 and from mid-2010 to early 2012 .

Data concerning nano-microphytoplankton abundances were only available for the winters (January) in the 2001-2008 period (Fig. 7). Abundances were highest $(70 \times$ $10^{3}$ cells $\cdot \mathrm{L}^{-1}$ ) during 2001 , but they abruptly dropped to low concentrations $\left(3-10 \times 10^{3}\right.$ cells $\left.\cdot \mathrm{L}^{-1}\right)$ during the period 2002-2006. During 2006-2007, abundances again increased $\left(20-40 \times 10^{3}\right.$ cells $\left.\cdot \mathrm{L}^{-1}\right)$ and then decreased to less than $10 \times$ $10^{3}$ cells $\cdot \mathrm{L}^{-1}$ in 2008 .

\section{DISCUSSION}

At a global scale, carbon fixation via phytoplankton photosynthesis directly responds to climate variability (Behrenfeld et al. 2006). In the last decades, changes in the oceanic conditions have favored a worrisome trend towards decreasing fixation rates. Primary productivity depends on light and nutrient availability, and these factors are controlled by different dynamic processes in the ocean at different scales (Behrenfeld et al. 2009). PP trends have been difficult to assess due to the scarcity of available in situ data, and this is why a Chla-based index (Demarcq 2009) or models that use satellite-derived Chla data have been used (Behrenfeld et al. 2009); therefore, results are influenced by trends in Chla. negativas que se extendió desde 2003 hasta finales de 2007. Durante 2008 y entre 2010 y 2011 se presentó una recuperación en la concentración de Chla. Esta alternancia de anomalías positivas y negativas en la Chla puede contrastarse con los cambios interanuales en las condiciones hidrográficas y atmosféricas de la región ecuatorial, representadas por el Índice Multivariado de El Niño (MEI, por sus siglas en inglés) para el periodo de estudio (Fig. 6 b). El MEI indica un evento El Niño sobresaliente en 1998 (anomalías positivas), seguido de condiciones favorables a La Niña (anomalías negativas) para el periodo 1999-2002. Desde finales de 2002 hasta mediados de 2005 , se presentaron anomalías positivas, mientras que de 2007 a 2008 y de mediados de 2010 a inicios de 2012 se presentaron condiciones frías importantes.

Para las abundancias de nano-microfitoplancton, sólo se tuvieron datos para los inviernos (enero) del periodo 2001-2008 (Fig. 7). Las abundancias durante 2001 fueron las más altas $\left(70 \times 10^{3}\right.$ células $\left.\mathrm{L}^{-1}\right)$, pero posteriormente disminuyeron abruptamente $\left(3-10 \times 10^{3}\right.$ células $\left.\cdot \mathrm{L}^{-1}\right)$ en el periodo 2002-2006. Las abundancias aumentaron nuevamente a valores de $20-40 \times 10^{3}$ células $\cdot \mathrm{L}^{-1}$ durante el periodo 2006-2007, y luego disminuyeron a menos de $10 \times$ $10^{3}$ células $\cdot \mathrm{L}^{-1}$ en 2008 .

\section{DISCUSIÓN}

A escala global, la fijación de carbono vía fotosíntesis del fitoplancton responde directamente a la variabilidad climática (Behrenfeld et al. 2006). Los cambios en las condiciones oceánicas de las últimas décadas han favorecido una preocupante tendencia al descenso en la tasa de fijación de carbono. La PP depende de la disponibilidad de luz y nutrientes, factores que son controlados en los océanos por diferentes procesos dinámicos de diferentes escalas (Behrenfeld et al. 2009). Las tendencias de la PP han sido difíciles de evaluar debido a la escasez de datos in situ disponibles, por lo que se ha usado la Chla como índice (Demarcq 2009) o los modelos alimentados con información satelital de Chla (Behrenfeld et al. 2009); por tanto, los resultados son influenciados por las tendencias en Chla.

En general, el parámetro fotosintético $P_{o p t}^{B}$ ha sido clave en las estimaciones satelitales de PP, ya que ha permitido diferenciar la respuesta del fitoplancton, en términos de su tasa fotosintética, a las condiciones ambientales de los diferentes biomas oceánicos (Behrenfeld y Falkowsky 1997). Su aplicación ha sido menos utilizada debido, en parte, a la existencia de un algoritmo global y a la dificultad metodológica para la obtención de datos in situ. Esta dificultad es evidente cuando se compara el número de mediciones de dicho parámetro ( 450 en 20 años) con el número de mediciones de concentración de Chla ( $\sim 650$ por crucero). Los resultados demuestran que los máximos valores promedio de $P_{o p t}^{B}\left(\sim 6.0 \mathrm{mg} \mathrm{C} \cdot[\mathrm{mg} \mathrm{Chla}]^{-1} \cdot \mathrm{h}^{-1}\right)$ observados a los 17.0 y $21.5^{\circ} \mathrm{C}$ (Fig. 3a) fueron similares al promedio 


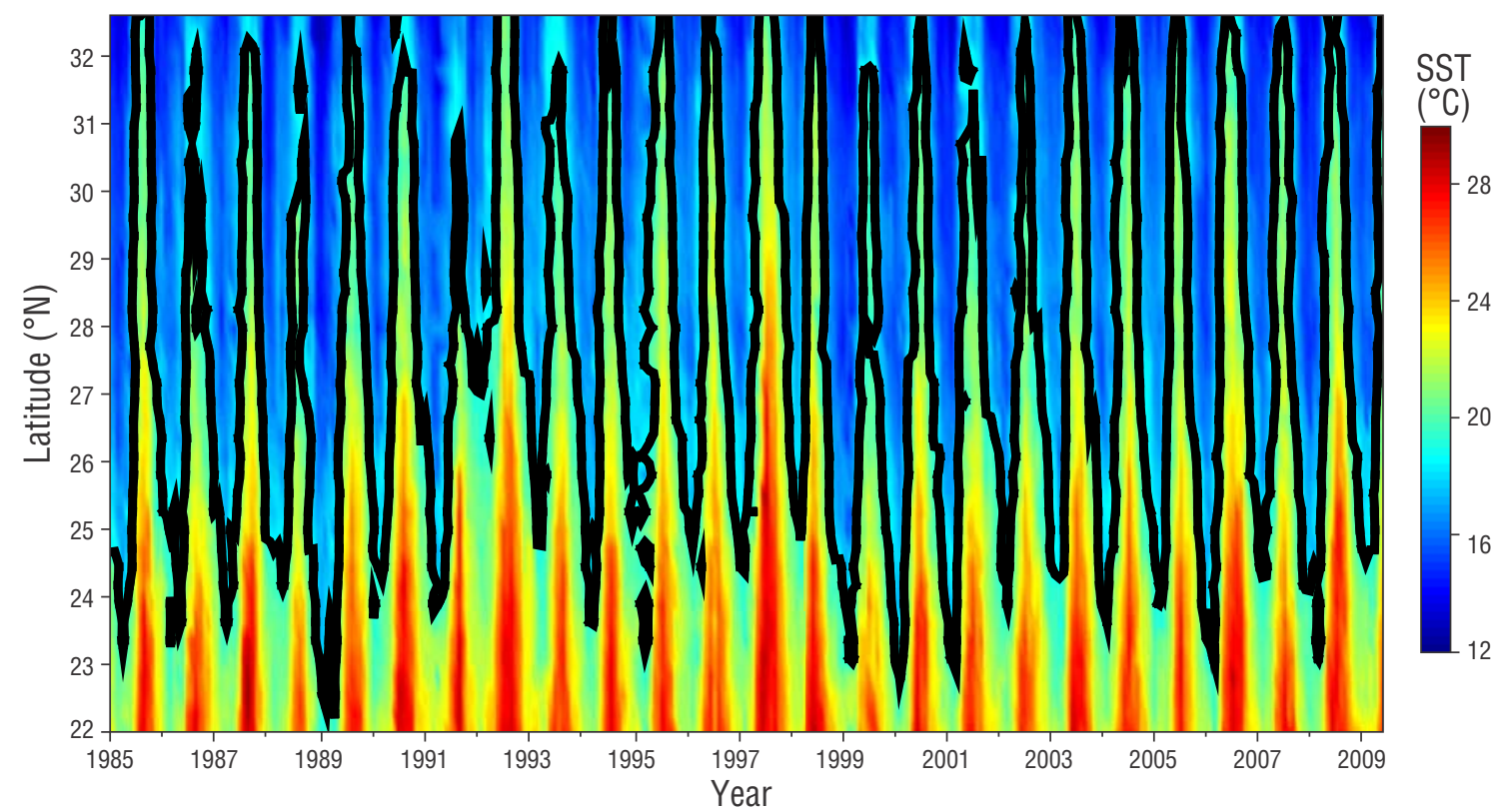

Figure 5. Spatiotemporal diagram of sea surface temperature (SST) variations for a transect located parallel to the coast (see Fig. 1).

Figura 5. Diagrama espaciotemporal de las variaciones de la temperatura superficial del mar (SST) para un transecto paralelo a la costa (ver Fig. 1).
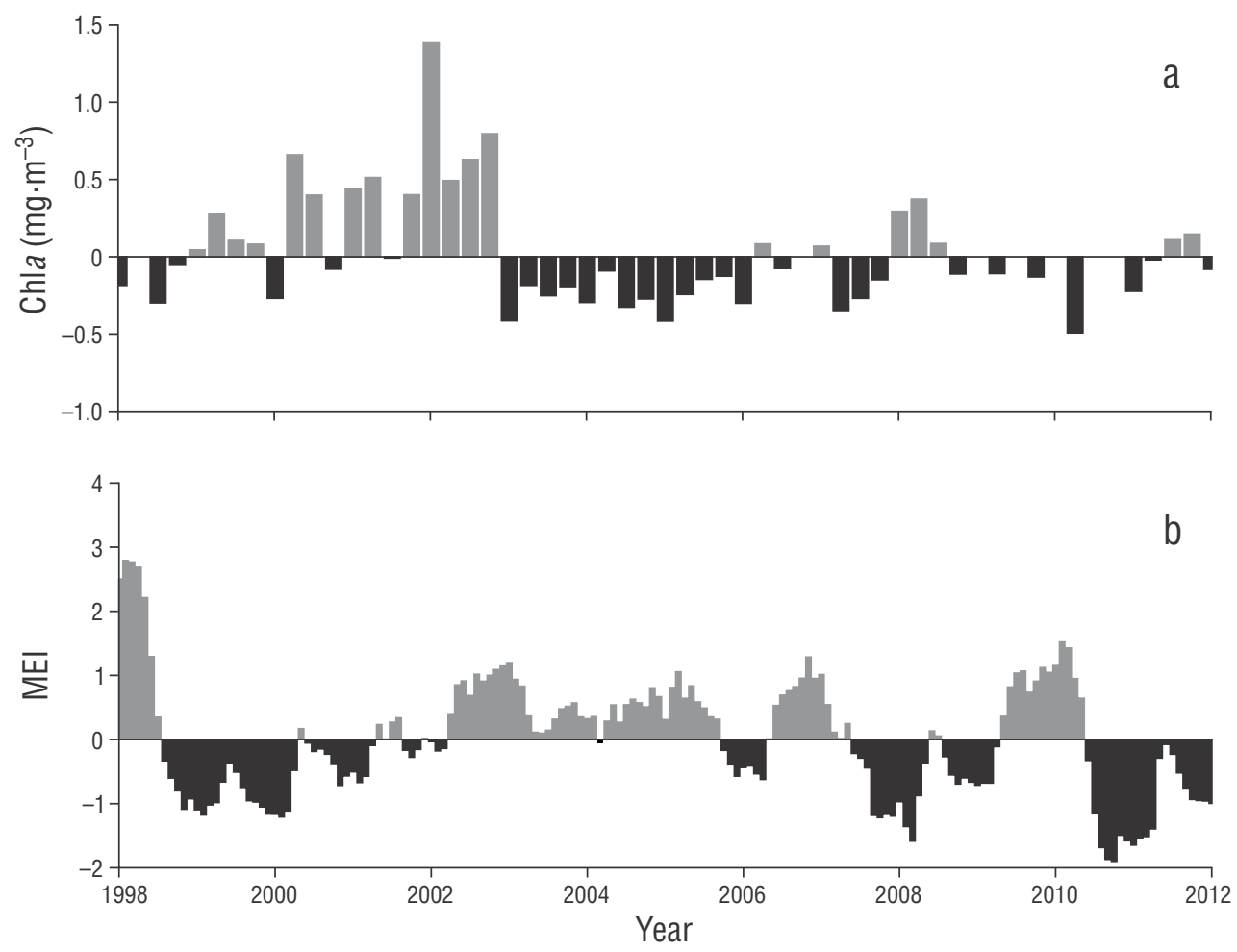

Figure 6. (a) Regional averages of chlorophyll (Chla) concentration anomalies $\left(\mathrm{mg} \cdot \mathrm{m}^{-3}\right)$ measured at $20 \mathrm{~m}$ depth, which corresponds to the depth closest to the position of the optimal rate of carbon fixation $\left(P_{o p t}^{B}\right)$ (Fig. 3B). (b) Temporal variation of El Niño Multivariate Enso Index (MEI) for the study period.

Figura 6. (a) Promedios regionales de las anomalías de la concentración de clorofila $\left(\mathrm{Chla}, \mathrm{mg} \cdot \mathrm{m}^{-3}\right.$ ) medida a $20 \mathrm{~m}$ de profundidad, que corresponde a la profundidad cercana a la posición de la tasa óptima de fijación de carbono $\left(P_{o p t}^{B}\right)$ (ver Fig. 3b). (b) Variación temporal del Índice Multivariado de El Niño (MEI) para el periodo de estudio. 
The photosynthetic parameter $P_{\text {opt }}^{B}$ has been a key factor in PP satellite assessments on a global scale because it allows to identify the response of phytoplankton, in terms of its photosynthetic rate, to environmental conditions in different oceanic biomes (Behrenfeld and Falkowsky 1997). On a regional level, it has not been applied frequently due to the existence of a global algorithm and to the methodological difficulty in obtaining in situ data. This difficulty is evident when comparing the number of measurements of this parameter ( 450 in 20 years) with those of Chla concentrations ( $\sim 650$ per cruise). The results show that the maximum average $P_{\text {opt }}^{B}$ values $\left(\sim 6.0 \mathrm{mg} \mathrm{C} \cdot(\mathrm{mg} \mathrm{Chla})^{-1} \cdot \mathrm{h}^{-1}\right)$ observed at 17.0 and $21.5{ }^{\circ} \mathrm{C}$ (Fig. 3a) were similar to the overall mean $\left(\sim 6.5 \mathrm{mg} \mathrm{C} \cdot(\mathrm{mgChl} a)^{-1} \cdot \mathrm{h}^{-1}\right)$ at $20{ }^{\circ} \mathrm{C}$ (Behrenfeld and Falkowski 1997). The observed $P_{o p t}^{B}$ values showed a wide interval ranging, from 0.5 to $17.0 \mathrm{mgC}(\mathrm{mg} \mathrm{Chla})^{-1} \mathrm{~h}^{-1}$, which together with light and nutrient availability may indicate a change in phytoplankton community composition (Almazán-Becerril et al. 2012). The light-nutrient relationship in the euphotic zone is controlled by the vertical displacements of the pycnocline, which responds to the dynamic processes that act at different scales in the CCS (Durazo and Baumgartner 2002, Soto-Mardones et al. 2004, Durazo 2009, Espinosa-Carreón et al. 2012). The mechanisms involved in the rising of the pycnocline increase light and nutrient availability in the euphotic zone, favoring high PP rates. However, the dominant community composition should also be considered, since picoplankton (e.g., Prochlorococcus) shows high PP rates (Casey et al. 2007) and it is the dominant group above the pycnocline (Jonhson et al. 2006).

The established empirical regional relation between SST and $P_{o p t}^{B}$ for the southern region of the CCS (Cepeda-Morales et al. 2010) offers the opportunity to refine PP satellite estimates at a regional level and provides additional information on the response of the phytoplankton community in the region. The maximum photosynthetic rates and their relation to SST are characteristics of each species and/or groups and reach maximum values under specific temperature conditions (Eppley 1972). At a global level, the relationship between the $P_{o p t}^{B}$ and SST is related to large biomes (Behrenfeld and Falkowski 1997). At a regional level, our results suggest that it is possible to associate phytoplankton variations with $P_{o p t}^{B}$ and SST, as indicators of hydrographic conditions.

The zone division into 2 regions (north and south), for which the boundary has been delineated at Punta Eugenia, off Baja California, has been extensively documented. Our results show that the average spatial distribution of the $19{ }^{\circ} \mathrm{C}$ isotherm is related to the biogeographic zonation of the southern portion of the CCS (McClatchie et al. 2009), and its spatial variations clearly demonstrate the change in hydrographic conditions from cold to warm periods.

The interannual changes related to El Niño/La Niña that modify pycnocline depth generate negative Chla anomalies during warm events (deep pycnocline) and positive anomalies during cold events (shallow pycnocline) (Gaxiola et al.

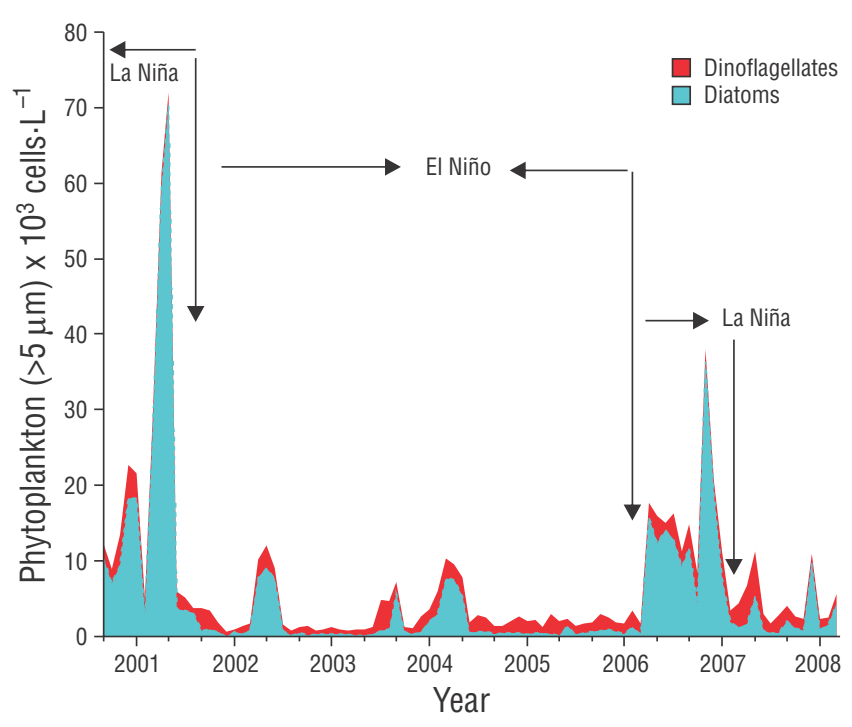

Figure 7. Temporal variation of the abundance and community composition of nano-microphytoplankton (diatoms and dinoflagellates) measured between 2001 and 2008. La Niña y El Niño interannual events are indicated (black arrows)

Figura 7. Variación temporal de la abundancia y composición comunitaria de nano-microfitoplancton (diatomeas y dinoflagelados) medida entre 2001 y 2008. Se indican los periodos de eventos interanuales de La Niña y El Niño (flechas negras)

global $\left(\sim 6.5 \mathrm{mg} \mathrm{C} \cdot[\mathrm{mg} \mathrm{Chla}]^{-1} \cdot \mathrm{h}^{-1}\right)$ a $20{ }^{\circ} \mathrm{C}$ (Behrenfeld y Falkowski 1997). Los valores observados de $P_{\text {opt }}^{B}$ tuvieron un amplio intervalo, de 0.5 hasta $17.0 \mathrm{mg} \mathrm{C} \cdot(\mathrm{mg} \mathrm{Chla})^{-1} \cdot \mathrm{h}^{-1}$, lo cual en conjunto con la disponibilidad de luz y nutrientes puede indicar un cambio en la composición de la comunidad del fitoplancton (Almazán-Becerril et al. 2012). La relación entre la luz y los nutrientes de la zona eufótica está controlada por los desplazamientos verticales de la picnoclina, la cual responde a los procesos dinámicos que actúan a diferentes escalas en el SCC (Durazo y Baumgartner 2002, SotoMardones et al. 2004, Durazo 2009, Espinosa-Carreón et al. 2012). Los mecanismos que elevan la picnoclina aumentan la disponibilidad de luz y nutrientes en la zona eufótica y favorecen altas tasas de PP. Sin embargo, también se debe considerar la composición comunitaria dominante, debido a que el picoplancton (e.g., Prochlorococcus) tiene altas tasas de PP (Casey et al. 2007) y es dominante por encima de la picnoclina (Jonhson et al. 2006).

La relación empírica regional entre la TSM y $P_{o p t}^{B}$ establecida para la región sur del SCC (Cepeda-Morales et al. 2010) ofrece la oportunidad de mejorar las estimaciones satelitales de PP a nivel regional y proporciona información adicional sobre la respuesta de la comunidad del fitoplancton en la región. Las tasas máximas fotosintéticas y su relación con la TSM son características de especies y/o grupos, y alcanzan valores máximos bajo condiciones de temperatura específicas (Eppley 1972). A nivel global, la relación entre $P_{\text {opt }}^{B}$ y TSM 
2008, Espinosa-Carreón 2012). However, the changes that occurred between mid-2002 and late 2007 (El Niño) (Fig. 6b), which yielded negative Chla anomalies (Fig. 6a), caused high $P_{o p t}^{B}$ values (Fig. 3a). Moreover, data on the nanomicrophytoplankton composition of the main groups (diatoms and dinoflagellates) (Fig. 7) indicate a decrease in cell abundances $\left(<10 \times 10^{3}\right.$ cells $\left.\cdot \mathrm{L}^{-1}\right)$, which coincides with the increase in $P_{\text {opt }}^{B}$ (Fig. 3a). These results suggest that there is a community change since low vertical flow of nutrients and warm conditions favor the dominance of picoplankton, which have high photosynthesis rates (Sosa-Avalos et al. 2010).

Some of the main groups in the phytoplankton community composition of the southern region of the CCS are picoplankton (Prochlorococcus, Synecococcus, and picoeukaryotes; Almazán-Becerril et al. 2012) and nanomicrophytoplankton (several species of diatoms and dinoflagellates; Millán-Núñez et al. 2004, Millán-Núñez and MillánNúñez 2010, Linacre et al. 2012). The contribution of picoplankton to biomass is of $46 \%$ during winter (MillánNúñez and Millán-Núñez 2010), though this group is also present in the ecosystem throughout the year (Barocio-León et al. 2006, Almazán Becerril et al. 2012). Martínez-Almeida et al. (2014) reported that the contribution to picoplankton biomass in 2008 was almost constant throughout the year and that major changes occurred due to variations in diatom and dinoflagellate abundances. In addition, despite the low biomass, cells that make up picoplankton are able to contribute about $50 \%$ of global PP due to their large abundance (Casey et al. 2007, Johnson et al. 2006).

The worldwide trend towards increasing ocean temperatures affects the stability of the water column and the variability of the mixed layer, modifying nutrient availability for phytoplankton (Boyce et al. 2010) and carrying worrying consequences for each ecosystem. Nevertheless, these consequences are still not clear, for each region responds in different ways (Belkin 2009). The pelagic ecosystem off the coast of the Baja California Peninsula seasonally changes its hydrographic conditions from cold to warm periods due to its transitional nature. These oscillations have been intensified by interannual (El Niño/La Niña) and decadal events. Under these conditions, the response of primary producers has proven to be different in terms of biomass and carbon fixation rate or PP. In the northern region of the CCS, the data for integrated PP have shown a marked seasonal pattern. However, long-period trends that give evidence of climate change effects have not yet been reported (Kahru et al. 2009). Nevertheless, the clear patterns of seasonal and interannual variabilities with the temporal variation in Chla are consistent with changes in hydrographic conditions; Chla increases during cold periods and decreases during warm periods, with a long-period tendency to decrease in the oceanic zone (Behrenfeld et al. 2009). The response of primary producers in the southern region of the CCS has shown high $P_{o p t}^{B}$ values that are apparently associated with community adjustments, está asociada a los grandes biomas (Behrenfeld y Falkowski 1997). A nivel regional, nuestros resultados sugieren que es posible asociar las variaciones del fitoplancton en términos del $P_{o p t}^{B}$ y de la TSM, como indicadores de las condiciones hidrográficas.

Frente a Baja California, la zonación en 2 regiones, norte y sur, cuyo límite se ha definido en punta Eugenia, ha sido ampliamente documentada. De acuerdo con los resultados, la distribución espacial promedio de la isoterma de $19{ }^{\circ} \mathrm{C}$ está asociada con la zonación biogeográfica de la región sur del SCC (McClatchie et al. 2009), y sus variaciones espaciales demuestran claramente el cambio de las condiciones hidrográficas de frías a cálidas.

Los cambios interanuales asociados con El Niño y La Niña que modifican la profundidad de la picnoclina generan anomalías negativas de Chla durante eventos cálidos (picnoclina profunda) y anomalías positivas durante eventos fríos (picnoclina somera) (Gaxiola-Castro et al. 2008, EspinosaCarreón 2012). Sin embargo, los cambios ocurridos entre mediados de 2002 y finales de 2007 (El Niño, Fig. 6b), que provocaron anomalías negativas de Chla (Fig. 6a), generaron altos valores en $P_{\text {opt }}^{B}$ (Fig. 3a). Por otro lado, los datos de la composición comunitaria del nano-microfitoplancton de los principales grupos (diatomeas y dinoflagelados, Fig. 7) indican que en ese periodo ocurrió una disminución en las abundancias celulares $\left(<10 \times 10^{3}\right.$ células $\left.\cdot \mathrm{L}^{-1}\right)$, coincidente con el aumento de $P_{o p t}^{B}$ (Fig. 3a). Estos resultados sugieren que existe un cambio comunitario debido a que, bajo condiciones cálidas y con bajo flujo vertical de nutrientes, se favorece la dominancia del picoplancton, grupo de organismos que se caracterizan por las altas tasas de fotosíntesis (Sosa-Avalos et al. 2010).

Entre los principales grupos que constituyen la composición comunitaria del fitoplancton de la región sur del SCC se encuentran el picoplancton (Prochlorococcus, Synecococcus y picoeucariontes; Almazán-Becerril et al. 2012) y el nanomicrofitoplancton (varias especies de los grupos de diatomeas y dinoflagelados; Millán-Núñez et al. 2004, MillánNúñez y Millán-Núñez 2010, Linacre et al. 2012). La contribución del picoplancton a la biomasa es del orden del 46\% para invierno (Millán-Núñez y Millán-Núñez 2010), aunque este grupo se encuentra en el ecosistema durante todo el año (Barocio-León et al. 2006, Almazán Becerril et al. 2012). Martínez-Almeida et al. (2014) documentaron que la contribución del picoplancton a la biomasa durante 2008 se mantuvo casi constante a lo largo del año y que los cambios importantes ocurrieron debido a las variaciones en las abundancias de diatomeas y dinoflagelados. Además, se ha reportado que, a pesar de su baja biomasa, las células que componen el picoplancton son capaces de contribuir con cerca del 50\% de la PP a nivel global debido a su gran abundancia (Casey et al. 2007, Johnson et al. 2006).

La tendencia global al incremento del calentamiento de los océanos afecta la estabilidad de la columna de agua y la variabilidad de la capa de mezcla, lo que modifica la 
which could be explained by the contribution of picoplankton due to its high growth rates.

\section{ACKNOWLEDGMENTS}

This work is dedicated to Gilberto Gaxiola-Castro ${ }^{\dagger}$, who dedicated his last 20 years to the study of primary producers in the IMECOCAL region. The IMECOCAL program was supported by the National Council for Science and Technology (CONACYT, Mexico; projects G0041T, 017Pñ-1297, G35326T, C0125343, C02-42569, 47044, 23947, 48367) and by the SEMARNAT-CONACYT fund (23804). The authors would like to thank CICESE for supporting the IMECOCAL program and the crew members of the R/V Francisco de Ulloa. Thanks are due to Francisco Ponce for editing the figures. SST satellite data were obtained from the NASA EOSDIS Physical Oceanography Distributed Active Archive Center (PO.DAAC) at the Jet Propulsion Laboratory, Pasadena, California.

\section{REFERENCES}

Aguirre-Hernández E, Gaxiola-Castro G, Najera-Martinez S, Baumgartner T, Kahru M, Mitchell G. 2004. Phytoplankton absorption, photosynthetic parameters and primary production off Baja California: summer and autumn 1998. Deep-Sea Res. II 51(6-9): 799-816.

http://dx.doi.org/10.1016/j.dsr2.2004.05.015

Almazán-Becerril A, Rivas D, García-Mendoza E. 2012. The infuence of mesoscale physical structures in the phytoplankton taxonomic composition of the subsurface chlorophyll maximum off western Baja California. Deep-Sea Res. I 70: 91-102. http://dx.doi.org/10.1016/j.dsr.2012.10.002

Barocio-León O, Millán-Núñez R, Santamaria-Del-Ángel E, González-Silvera A, Trees C. 2006. Spatial variability of phytoplankton absorption coefficients and pigments off Baja California during November 2002. J. Oceanogr. 62: 873-885.

Belkin Igor M. 2009. Rapid warming of large marine ecosystems. Prog. Oceanogr. 81(1-4): 207-213.

http://dx.doi.org/10.1016/j.pocean.2009.04.011

Behrenfeld MJ, Falkowski PG. 1997. Photosynthetic rates derived from satellite-based chlorophyll concentration. Limnol. Ocean. 42(1): $1-20$. http://dx.doi.org/10.4319/1o.1997.42.1.0001

Behrenfeld MJ, O’Malley RT, Siegel DA, McClain CR, Sarmiento JL, Feldman GC, Milligan AJ, Falkowski PG, Letelier RM, Boss ES. 2006. Climate-driven trends in contemporary ocean productivity. Nature. 444(7120): 752-755. http://dx.doi.org/10.1038/nature05317

Behrenfeld MJ, Siegel DA, O’Malley RT, Maritorena S. 2009. Global Ocean phytoplankton. In: Peterson TC, Baringer MO (eds.), State of the climate in 2008. Bull. Amer. Meteor. Soc. 90: S568-S573.

Boyce DG, Lewis MR, Worm B. 2010. Global phytoplankton decline over the past century. Nature. 466(7306): 591-596. http://dx.doi.org/10.1038/nature09268

Carr ME, Friedrichs MAM, Schmeltz M, Aita MN, Antoine D, Arrigo KR, Asanuma I, Aumont O, Barber R, Behrendeld M, et al. 2006. A comparison of global estimates of marine primary production from ocean color. Deep-Sea Res. II 53(5-7): 741-770.

http://dx.doi.org/10.1016/j.dsr2.2006.01.028 disponibilidad de nutrientes para el fitoplancton (Boyce et al. 2010) y tiene preocupantes consecuencias para los ecosistemas, que aún no son claras debido a que cada región responde de manera diferente (Belkin 2009). El ecosistema pelágico frente a las costas de la península de Baja California, debido a su carácter transicional, mantiene el continuo cambio estacional de las condiciones hidrográficas de frías a cálidas. Estas oscilaciones se han visto acentuadas por eventos interanuales (El Niño y La Niña) y decadales. Bajo estas condiciones, la respuesta de los productores primarios ha demostrado ser diferente entre la biomasa y la tasa de fijación de carbono o PP. En la región norte del SCC, los datos de PP integrada poseen un marcado patrón estacional; sin embargo, aún no se han documentado tendencias de largo periodo que permitan evidenciar efectos del cambio climático (Kahru et al. 2009). Por otra parte, se han encontrado claros patrones de variabilidad estacional e interanual en la variación temporal de Chla consistentes con los cambios de las condiciones hidrográficas como, por ejemplo, los incrementos en las fases frías y descensos en las fases cálidas, y una tendencia de largo periodo hacia el descenso en la parte oceánica (Behrenfeld et al. 2009). La respuesta de los productores primarios en la región sur del SCC ha mantenido elevadas tasas de $P_{o p t}^{B}$ aparentemente asociadas a los ajustes comunitarios, lo cual podría ser explicado por la contribución del picoplancton debido a sus altas tasas de crecimiento.

\section{Agradecimientos}

Este trabajo está dedicado a Gilberto Gaxiola-Castro ${ }^{\dagger}$, quien enfocó sus últimos 20 años al estudio de los productores primarios en la región IMECOCAL. El programa IMECOCAL recibió apoyo del Consejo Nacional de Ciencia y Tecnología (CONACYT, México; proyectos G0041T, 017Pñ-1297，G35326T， C0125343， C02-42569，47044, 23947, 48367) y del fondo SEMARNAT-CONACYT (23804). Los autores agradecen al CICESE el apoyo al programa IMECOCAL, y a la tripulación del B/O Francisco de Ulloa, así como a Francisco Ponce su apoyo en la edición de figuras. Los datos satelitales de TSM fueron adquiridos del NASA EOSDIS Physical Oceanography Distributed Active Archive Center (PO.DAAC) del Jet Propulsion Laboratory, Pasadena, California.

English translation by Sofía Garduño.

Casey J, Lomas M, Mandecki J, Walker D. 2007. Prochlorococcus contributes to new production in the Sargasso Sea deep chlorophyll maximum. Geophys. Res. Lett. 34, L106604. http://dx.doi.org/10.1029/2006GL028725

Cepeda-Morales J, Gaxiola-Castro G, Durazo R, De la Cruz-Orozco ME. 2010. Productividad primaria modelada. In: GaxiolaCastro G, Durazo R (eds.), Dinámica del Ecosistema Pelágico frente a Baja California, 1977-2007: Diez años de Investigaciones Mexicanas de la Corriente de California. 2010. Secretaría de Medio Ambiente y Recursos Naturales, Mexico, pp. 59-85. 
Demarcq Hervé. 2009. Trends in primary production, sea surface temperature and wind in upwelling systems (1998-2007). Progr. Oceanogr. 83(1-4): 376-385.

http://dx.doi.org/10.1016/j.pocean.2009.07.022

Durazo R. 2009. Climate and upper ocean variability off Baja California, México: 1997-2008. Prog. Oceanogr, 83(1-4): 361-368. http://dx.doi.org/10.1016/j.pocean.2009.07.043

Durazo R. 2015. Seasonality of the transitional region of the California Current System off Baja California. Journal of Geophysical Research 120(2): 1173-1196. http://dx.doi.org/10.1002/2014JC010405

Durazo R, Baumgartner TR. 2002. Evolution of oceanographic conditions off Baja California, 1997-1999. Prog. Oceanogr. 54(1-4): 7-31.

http://dx.doi.org/10.1016/S0079-6611(02)00041-1

Eppley R. 1972. Temperature and phytoplankton growth in the sea. Fish. Bull. 70(4): 1063-1081.

Espinosa-Carreón TL, Gaxiola-Castro G, Durazo R, De la CruzOrozco ME, Norzagaray-Campos M, Solana-Arellano E. 2015. Influence of anomalous subarctic water intrusion on phytoplankton production off Baja California. Cont. Shelf Res. 92: 108-121.

http://dx.doi.org/10.1016/j.csr.2014.10.003

Espinosa-Carreón TL, Gaxiola-Castro G, Emilio Beier, Strub T, Kurczyn JA. 2012. Effects of mesoscale processes on phytoplankton chlorophyll off Baja California. J. Geophys. Res. 117 (C4). http://dx.doi.org/10.1029/2011JC007604

Espinosa-Carreón TL, Strub PT, Beier E, Ocampo-Torres F, Gaxiola-Castro G. 2004. Seasonal and interannual variability of satellite-derived chlorophyll pigment, surface height, and temperature off Baja California. J. Geophys. Res. 109 (C03039). http://dx.doi.org/10.1029/2003JC002105

Gaxiola-Castro G, Durazo R, Lavaniegos B, De la Cruz-Orozco, Millán-Núñez E, Soto-Mardones L, Cepeda-Morales J. 2008. Pelagic ecosystem response to interannual variability off Baja California $=$ Respuesta del ecosistema pelágico a la variabilidad interanual del océano frente a Baja California. Cien. Mar. 34(2): 263-270.

Gaxiola-Castro G, Lavaniegos B, Martínez A, Castro R, EspinosaCarreón TL. 2010. Pelagic ecosystem response to climate variability in the Pacific Ocean off Baja California. pp. 163-182. In: SW Simard and ME Austin (eds.). Climate Change and Variability. Sciyo Books, 486 pp. http://dx.doi.org/ 10.5772/9807

Holm-Hansen O, Lorenzen CJ, Holmes RW, Strickland JDH. 1965. Fluorometric determination of chlorophyll. J. Cons. Perm. Int. Expl. Mer 30(1): 3-15 http://dx.doi.org/10.1093/icesjms/30.1.3

Johnson ZI, Zinser ER, Coe A, McNulty NP, Woodward EM, Chisholm SW. 2006. Niche partitioning among Prochlorococcus ecotypes along ocean-scale environmental gradients. Science. 311 (5768): 1737-1740.

http://dx.doi.org/10.1126/science.1118052
Kahru M, Kudela R, Manzano-Sarabia M, Mitchell G. 2009. Trends in primary production in the California Current detected with satellite data. J. Geophys. Res. 114(C2): C02004. http://dx.doi.org/10.1029/2008JC004979

Lavaniegos, BE. 2009. Influence of a multiyear event of low salinity on the zooplankton from Mexican eco-regions of the California Current. Prog. Oceanogr. 83(1-4): 369-375. http://dx.doi.org/10.1016/j.pocean.2009.07.037

Linacre L, Durazo R, Hernández-Ayón JM, Delgadillo-Hinojosa F, Cervantes-Díaz G, Lara-Lara JR, Camacho-Ibar V, SiqueirosValencia A, Bazán-Guzmán C. 2010. Temporal variability of the physical and chemical water characteristics at a coastal monitoring observatory: Station Ensenada. Cont. Shelf Res. 30(16): 1730-1742. http://dx.doi.org/10.1016/j.csr.2010.07.011

Linacre L, Landry M, Cajal-Medrano R, Lara-Lara R, HernándezAyón M, Mouriño-Perez R, Garcia-Mendoza E, Bazán-Guzmán. 2012. Temporal dynamics of carbon flow through the microbial plankton community in a coastal upwelling system off northern Baja California, Mexico. Mar. Ecol. Prog. Ser. 461: 31-46. http://dx.doi.org/10.3354/meps09782

Martinez-Almeida V, Gaxiola-Castro G, Durazo R, Lara-Lara R. 2014. Phytoplankton size-fractionated chlorophyll- $a$ off Baja California during winter, spring, and summer 2008. Hidrobiológica. 24(3): 191-206.

McClatchie S, Goericke R, Schwing FB, Bograd SJ, Peterson WT, Emmett R, Charter R, Watson W, Lo N, Hill K, et al. 2009. The state of the California Current, spring 2008-2009: cold conditions drive regional differences in coastal production. CalCOFI Rep. 50: 43-68.

Millán-Núñez E, Millán-Núñez R. 2010. Specific absorption coefficient and phytoplankton community structure in the southern region of the California Current during January 2002. J. Ocean. 66: 719-730.

Millán-Núñez E, Sieracki ME, Millán-Núñez R, Lara-Lara JR, Gaxiola-Castro G, Trees C. 2004. Specific absorption coefficient and phytoplankton biomass in the southern region of the California Current. Deep-Sea Res. II. 51: 817-826.

Parsons TR, Maita T, Lalli CM. 1984. A manual of chemical and biological methods for seawater analysis. Pergamon Press. Oxford, UK, 173 pp.

Sosa-Avalos R, Gaxiola-Castro G, Mitchell BG, Cepeda-Morales J. 2010. Parámetros fotosintéticos y producción primaria estimada a partir de sensores remotos durante 1999. In: Gaxiola-Castro G, Durazo R (eds.), Dinámica del Ecosistema Pelágico frente a Baja California, 1977-2007: Diez años de Investigaciones Mexicanas de la Corriente de California. 2010. Secretaría de Medio Ambiente y Recursos Naturales, Mexico, pp. 319-331.

Soto-Mardones L, Parés-Sierra A, García J, Durazo R, Hormazabal S. 2004. Analysis of the mesoscale structure in the IMECOCAL region (off Baja California) from hydrographic, ADCP and altimetry data. Deep-Sea Res. II 51: 785-798.

Venrick EL, Hayward TL. 1984. Determining chlorophyll on the 1984 CalCOFI surveys. CalCOFI Rep. 25: 74-79.

Yentsch C S, Menzel DW. 1963. A method for the determination of phytoplankton chlorophyll and phaeophytin by fluorescence. Deep-Sea Res. 10: 221-231.

Received March 2017, accepted June 2017. 